\title{
Hydrological modelling in the anthroposphere: predicting local runoff in a heavily modified high-alpine catchment
}

\author{
Johannes WESEMANN iD http://orcid.org/oooo-0oo2-4200-9340; e-mail: johannes.wesemann@boku.ac.at \\ Mathew HERRNEGGER* (i) http://orcid.org/oooo-0oo2-5388-2831; Me-mail: mathew.herrnegger@boku.ac.at \\ Karsten SCHULZ iD http://orcid.org/oooo-0002-6616-2876; e-mail: karsten.schulz@boku.ac.at \\ * Corresponding author \\ Institute of Water Management, Hydrology and Hydraulic Engineering (IWHW); University of Natural Resources and Life \\ Sciences, Vienna (BOKU), Muthgasse 18, 1190 Vienna, Austria
}

\begin{abstract}
Citation: Wesemann J, Herrnegger M, Schulz K (2018) Hydrological modelling in the anthroposphere: predicting local runoff in a heavily modified high-alpine catchment. Journal of Mountain Science 15(5). https://doi.org/10.1007/s11629017-4587-5
\end{abstract}

(C) The Author(s) 2018, corrected publication 06/2018

\begin{abstract}
Hydrological models within inflow forecasting systems for high-alpine hydropower reservoirs can provide valuable information as part of a decision support system for the improvement of hydropower production or flood retention. The information, especially concerning runoff, is however rarely available for the calibration of the hydrological models used. Therefore, a method is presented to derive local runoff from secondary information for the calibration of the model parameters of the rainfallrunoff model COSERO. Changes in water levels in reservoirs, reservoir outflows, discharge measurements at water intakes and in transport lines are thereby used to derive the local, "natural" flow for a given sub-catchment. The proposed method is applied within a research study for the ÖBB Infrastructure Railsystem division in the Stubache catchment in the central Austrian Alps. Here, the ÖBB operates the hydropower scheme "Kraftwerksgruppe Stubachtal", which consists of 7 reservoirs and 4 hydropower stations. The hydrological model has been set up considering this human influences and the high natural heterogeneity in topography and land cover, including glaciers. Overall, the hydrological model performs mostly well for the catchment with highest NSE values of 0.78 for the calibration and 0.79 for the validation period, also considering the use of homogeneous parameter fields and the
\end{abstract}

\footnotetext{
Received: 07 July 2017

1 $^{\text {st }}$ Revision: 27 March 2018

$2^{\text {nd }}$ Revision: 28 February 2018
}

Accepted: 03 April 2018 uncertainty of the derived local discharge values. The derived runoff data proved to be useful information for the model calibration. Further analysis, examining the water balance and its components as well as snow cover, showed satisfactory simulation results. In conclusion, a unique runoff dataset for a small scale high-alpine catchment has been created to establish a hydrological flow prediction model which in a further step can be used for improved and sustainable hydropower management.

Keywords: High alpine catchments; Rainfall-runoff modelling; Hydropower; Ungauged basins

\section{Introduction}

The European Alps are the water towers of large parts of Europe (Viviroli et al. 2007). Important river systems, including the Danube, Rhine, Rhone and Po, have their sources in the Alps and support millions of people, not only in the headwater areas but also in downstream regions. The uplift and subsequent cooling of air due to the high elevations and the general east-west orientation of the Alpine Arch lead to high precipitation sums. This is caused by moist weather systems originating from the Mediterranean in the south and from the Atlantic in the north-west. The low temperature due to the high elevation also causes storage of precipitation as snow over the 
winter season. The melting of the snowpack in spring and summer leads to a distinguished runoff seasonality in months in which water demand tends to be high (Čenčur Curk et al. 2014). Additionally, the climatic characteristics, the prolonged periods of snow cover and the shorter vegetation periods result in comparatively low losses of water to the atmosphere from evapotranspiration (Herrnegger et al. 2012; de Jong 2002; Lang 1981). The system can be characterized as energy limited (Budyko 1974), meaning that the evapotranspiration is limited by the available energy input into the system and not by water availability. In consequence, high runoff is available for downstream regions, not only for groundwater recharge along major rivers. On average, the Alps contribute between 26\% (Danube) to $53 \%$ (Po) to the total discharge although their share of Alpine space in relation to the overall catchment tends to be low (e.g. $10 \%$ and $35 \%$ in the case of the Danube and Po). In summer, the contribution to runoff can rise to $80 \%$, as is the case with the Po River (Alpine Convention 2009).

Large gradients in combination with high runoff volumes provide an ideal setting for hydropower production. About $40000 \mathrm{MW}$ of installed power are available from hydropower stations in the Alps, whereas the contribution to the overall electrical energy production is about $55 \%$ to $65 \%$ in single countries like Austria or Switzerland (Alpine Convention 2009; Bätzing 1997; Eurostat 2017). Hydropower reservoirs and pumped-storage facilities play an important role, not only as seasonal storages, but also for the short-term provision of electrical energy. These facilities satisfy peak demands and stabilize the electricity grid, especially in the wake of the increase in renewables in the electricity mix (Duque et al. 2011; Kapsali and Kaldellis 2010; Suberu et al. 2014; Zhao et al. 2015). The share of energy from renewable sources for electricity in the EU-28 has risen from $14.3 \%$ in 2004 to $28.8 \%$ in 2015. The increase is mainly attributed to wind and solar photovoltaic energy systems (Eurostat 2017), which are however characterized by a high spatial and temporal variability in production due to external weather factors.

Apart from electricity production, hydropower reservoirs can have effects on flood management and can lead to the retention of flood peaks in the headwater areas. In periods of low flows, reservoirs can provide additional water resources for increasing flow. In the Danube Alpine headwaters, a storage volume of reservoirs of about 1900 million $\mathrm{m}^{3}$ is available (Alpine Convention 2009). This volume would translate into a mean annual discharge of $60 \mathrm{~m}^{3} / \mathrm{s}$, compared to a mean annual runoff of $1925 \mathrm{~m}^{3} / \mathrm{s}$ of the Danube at Vienna (BMLFUW 2013).

Due to the reasons stated above and also for short-term energy production in the context of intraday power trading, hydrological forecasting models can provide valuable and objective information for decision makers improving the management of reservoir water levels (Hamlet et al. 2002; McGuire et al. 2006; Regonda et al. 2006). The main aim of these forecasting model applications is thereby the simulation of the local runoff contribution into the system. With this information the reservoir management rules (e.g. for hydropower production or flood retention) can be applied. Based on meteorological forecasts, the hydrological models provide runoff estimates into the reservoir system with typical lead times of 48 hours to 14 days into the future. The meteorological forecasting skill and in consequence the quality of the runoff prediction however drop significantly with longer lead times (Stern and Davidson 2015). The range of hydrological models in use varies widely and ranges from empirical (e.g. Artificial Neural Network Models, Ghumman et al. 2011), to conceptual (e.g. HBV, Bergström 1995) and more physically based models (SHE/ MIKE SHE, Abbot et al. 1986). Devi et al. (2015) give a brief comparison of the model types. Usually, the widely used conceptual hydrological forecasting models and their parameters are calibrated based on historical observations of meteorological parameters (e.g. precipitation and temperature) and runoff. Standardized and long-term measurements capturing the small-scale variability, especially of runoff, are generally rare in high-alpine settings. However, the calibration on the basis of historical data is inevitable to achieve the needed performance (Holländer et al. 2009). Integrating a multi-objective calibration procedure, e.g. including snow cover data or water balance indicators, can lead to an improvement of the model outputs as Finger et al. (2011, 2015) show. 
Various methods exist to derive snow cover products (e.g. Thirel et al. 2013; Pardo-Iguzquiza et al. 2017; Härer et al. 2016) or already existing data products can be used (e.g. CryoLand, 2017).

The ÖBB Infrastructure, which is part of the Austrian Federal Railways, operates the hydropower scheme "Kraftwerksgruppe Stubachtal" in the Stubache catchment in the central Austrian Alps in the state of Salzburg. The ÖBB Infrastructure initiated a research project with the intention of providing more precise inflow forecasts for their main hydropower stage. The hydropower scheme Stubachtal is one of the backbones of the ÖBB energy management system. It provides services like short term provision of electrical energy or black start capabilities to the electrical railway grid, which operates at $16.7 \mathrm{~Hz}$, in contrary to the common $50 \mathrm{~Hz}$ grid. An accurate inflow forecast will be an important step in the optimisation and operation of the reservoirs and hydropower plants.

For this research study, the ÖBB Infrastructure provided hydrological data from the catchment areas and reservoirs as well as topographical information. Nevertheless, this data does not include the local discharge data needed for the calibration of a hydrological forecasting model. In order to provide this data, we present a method to derive the local runoff for small catchments within a high-alpine hydropower scheme on the basis of secondary information. The local flow for several small catchments (range 0.4 $42.3 \mathrm{~km}^{2}$; mean $6.7 \mathrm{~km}^{2}$ ) is thereby estimated based on time series of reservoir outflows and water levels as well as from different discharge measurements at water intake structures and at outlets of transport lines. Subsequently, we present how this "natural" flow can be used for calibrating a conceptual hydrological model and how additional analyses of water balance components and snow cover area can help to further evaluate modelling results. Eventually, this model can be used within an inflow forecasting system.

\section{Database}

\subsection{Study area}

The presented method is developed utilising data from the Stubache catchment $\left(12.6^{\circ}\right.$ E, $47.2^{\circ}$
$\mathrm{N})$ in the central Austrian Alps in the state of Salzburg. The Stubache is a tributary to the Salzach, which drains via the Inn River into the Danube. A hydropower scheme is situated in the catchment and is managed by the ÖBB Infrastructure for electricity production in order to satisfy its energy demand. It consists of seven reservoirs and four main hydropower stations. The hydrology of the catchment is complex due to the significant influence by human activities. The Stubache has a natural (orographic) catchment area of $126.6 \mathrm{~km}^{2}$. Due to two main diversions, which transfer water from adjoining valleys, the effective catchment area increases to $141.3 \mathrm{~km}^{2}$ or $+11.6 \% .56 \mathrm{~km}^{2}$ or about $40 \%$ of the catchment is drained and transferred to reservoirs. The anthropogenic influence is further underlined by the huge amount of 29 water intake structures in the area, which are mainly used to divert and collect water in the reservoirs. For the spatial discretisation of the hydrological model, some of the subcatchments defined by these facilities were merged and including subcatchments defined by gauging stations and reservoirs a total of 21 subbasins ranging from 0.4 to $42.3 \mathrm{~km}^{2}$ were defined (Figure 1, Table 1).

The southern diversion drains four catchments south of the main alpine ridge (subbasins $1-4$ ) and one in the Stubache valley (subbasin 9). The small reservoir Beimsee, with a storage capacity of 1.1 million $\mathrm{m}^{3}$, is located within subbasin 1 . Water from the southern diversion flows into the main reservoir, the Tauernmossee (subbasin 12), which has a storage capacity of 55.3 million $\mathrm{m}^{3}$. Another diversion in the north connects two smaller reservoirs Ammersee (4.3 million $\mathrm{m}^{3}$, subbasin 5) and Salzplattensee (1.1 million $\mathrm{m}^{3}$, subbasin 6) and three water intakes (subbasin 7 ) to the Weissee reservoir (16 million $\mathrm{m}^{3}$, subbasin 8). The Weissee, a further diversion (subbasin 10) and the natural inflow from subbasin 11 drain into the Tauernmoossee. The smaller reservoirs are managed on an annual basis to improve the water availability in the main reservoir. The main reservoir is connected, together with subbasin 13, to the Enzingerboden power station (81 MW) located at the outlet of subbasin 15. A further water intake structure is located at the outlet of subbasin 14. Two headrace tunnels have their origin at the outlet of subbasin 15. An $11.6 \mathrm{~km}^{2}$ long pressure 

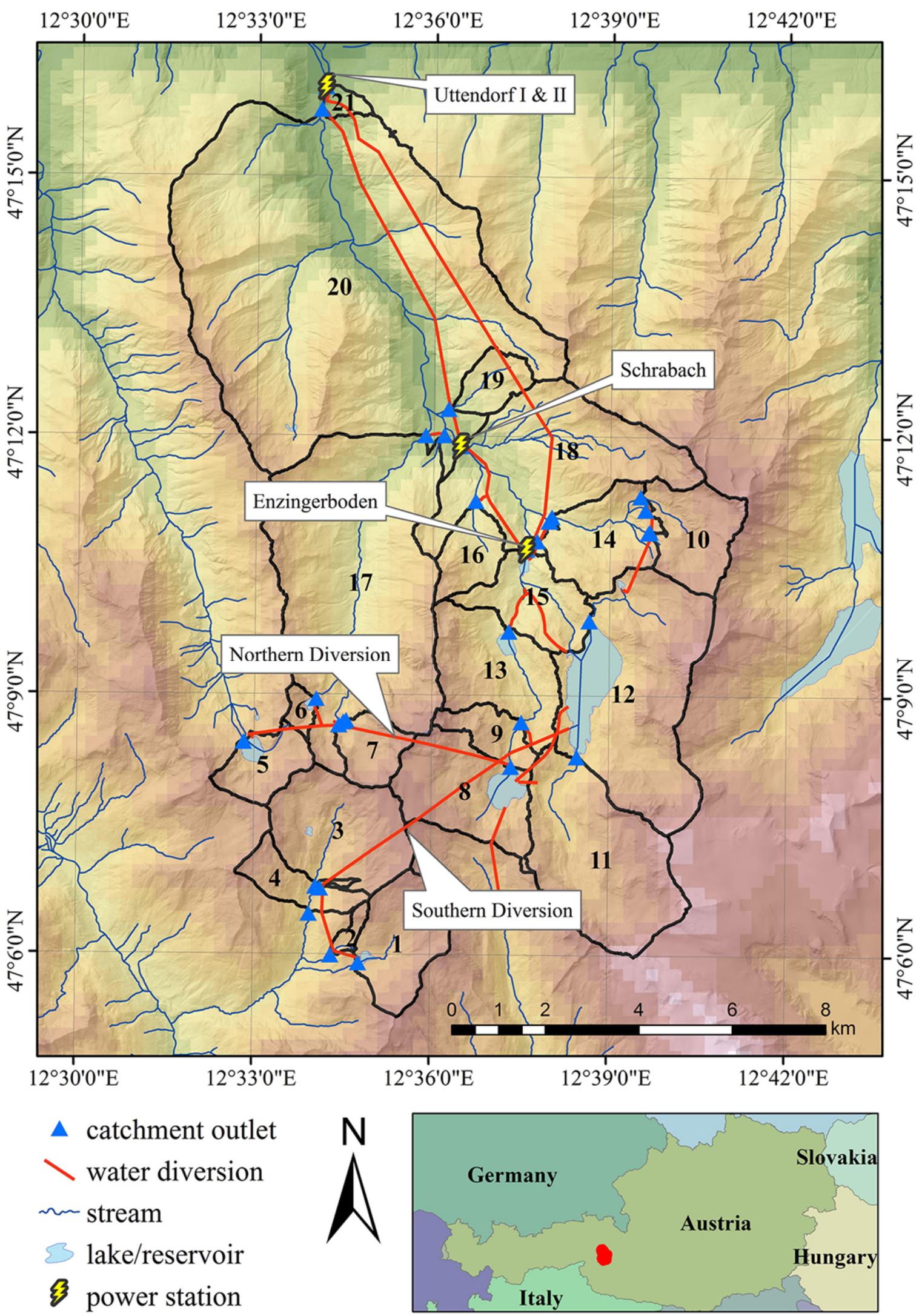

Figure 1 Study area, including subbasins, catchment outlets, water diversions, reservoirs and power stations. The location of the study area within Austria is marked in red in the small topological overview map. 
Table 2 Areas $\left(\mathrm{km}^{2}\right)$ and fractions of total area in \% for the soil type and the hydrogeology of the Stubache catchment

\begin{tabular}{|l|l|l|}
\hline Soil Type & $\mathrm{km}^{2}$ & $\%$ \\
\hline Cambisols & 8.5 & 6.0 \\
\hline Orthic Podzol & 78.7 & 55.7 \\
\hline Dystric Lithosol & 30.6 & 6.0 \\
\hline Rock outcrop/ glacier & 23.5 & 16.6 \\
\hline Hydrogeology & $\mathrm{km}^{2}$ & $\%$ \\
\hline Gravel and Sand, locally marl & 0.2 & $<0.1$ \\
\hline Carbonate rocks & 1.8 & 1.3 \\
Granite, gneiss and schist & 129.3 & 91.5 \\
\hline Phyllite and schist & 10.1 & 7.1 \\
\hline
\end{tabular}

tunnel directly heads to the Uttendorf II power station $(66 \mathrm{MW})$ at the overall catchment outlet. Another pressure pipeline, together with water from subbasin 16, leads to the Schneiderau power station $(35 \mathrm{MW})$ in subbasin 18 . The water is then, after including a diversion from subbasin 17 , led by a pressure tunnel to the Uttendorf I power station (27 MW). Subbasin 19 is not connected to the pressure tunnel and drains into subbasin 20, the residual water section. All flows come together in subbasin 21, the overall catchment outlet. All sub- catchments and the diversions are displayed in Figure 1. Additional information concerning the catchments is given in Table 1.

The topography of the catchment shows Alpine characteristics with an elevation range from $790 \mathrm{~m}$ a.s.l at the outlet up to $3450 \mathrm{~m}$ a.s.l in the southern summit areas. The land use, derived and aggregated from the CORINE 2012 Austria database (Umweltbundesamt 2017), is dominated by three classes: (1) high elevation areas with sparse vegetation and bare rock (37.5\%), (2) flatter areas with grassland and meadows (27.8\%) and (3) hillslope areas with mainly coniferous forests (26.2\%). Several glaciers exist in the catchment accumulating to $8.5 \mathrm{~km}^{2}(6.0 \%) .2 .3 \%$ of the area is occupied by the reservoirs leaving a negligible remaining share of $0.2 \%$ of agricultural area. Information on hydrogeology and the soil type is taken from the Hydrological Atlas of Austria (BMLFUW 2007) and the shares are displayed in Table 2.

The natural hydro-meteorological regime is highly influenced by low winter temperatures and

Table 1 Subbasins of the Stubache catchment including subbasin area, accumulated area, mean elevation, origin of local observed runoff and temporal resolution of runoff time series (outlets without observations are denoted with N/A).

\begin{tabular}{|c|c|c|c|c|c|c|}
\hline $\begin{array}{l}\text { Sub- } \\
\text { basin }\end{array}$ & Subbasin name & $\begin{array}{l}\text { Area } \\
\left(\mathrm{km}^{2}\right)\end{array}$ & $\begin{array}{l}\text { Area++ } \\
\left(\mathrm{km}^{2}\right)\end{array}$ & $\begin{array}{l}\text { Mean elevation } \\
\text { (m a.s.l) }\end{array}$ & $\begin{array}{l}\text { Local observed runoff } \\
\text { origin }\end{array}$ & $\begin{array}{l}\text { Temporal } \\
\text { resolution }\end{array}$ \\
\hline 1 & Beimsee & 4.13 & 4.13 & 2628 & Secondary information & $12 \mathrm{~h}$ \\
\hline 2 & Seetoerlbach & 0.40 & 0.40 & 2447 & Secondary information & $12 \mathrm{~h}$ \\
\hline 3 & $\begin{array}{l}\text { Upper Landeckbach/ } \\
\text { Moosbach }\end{array}$ & 6.09 & 6.09 & 2570 & Secondary information & $12 \mathrm{~h}$ \\
\hline 4 & Lower Landeckbach & 1.91 & 1.91 & 2402 & Secondary information & $12 \mathrm{~h}$ \\
\hline 5 & Amersee & 2.22 & 2.22 & 2501 & Secondary information & $24 \mathrm{~h}$ \\
\hline 6 & Salzplattensee & 0.52 & 0.52 & 2461 & Secondary information & $24 \mathrm{~h}$ \\
\hline 7 & $\begin{array}{l}\text { Eisbachl/ Upper } \\
\text { Oedtbach }\end{array}$ & 1.85 & 1.85 & 2601 & Secondary information & $24 \mathrm{~h}$ \\
\hline 8 & Weissee & 5.45 & 10.04 & 2562 & Secondary information & $24 \mathrm{~h}$ \\
\hline 9 & Schotterleitenbach & 1.65 & 1.65 & 2376 & Secondary information & $12 \mathrm{~h}$ \\
\hline 10 & Upper Wurfbach & 3.63 & 3.63 & 2593 & Direct measurement & $60 \mathrm{~min}$ \\
\hline 11 & Oedwinkelbach & 9.50 & 9.50 & 2568 & No/insufficient data & $\mathrm{N} / \mathrm{A}$ \\
\hline 12 & Tauernmoossee & 12.91 & 50.25 & 2420 & Secondary information & $24 \mathrm{~h}$ \\
\hline 13 & Gruensee & 5.47 & 5.47 & 2131 & No/insufficient data & $\mathrm{N} / \mathrm{A}$ \\
\hline 14 & $\begin{array}{l}\text { Lower Wurfbach/ } \\
\text { Roetentrogbach }\end{array}$ & 4.12 & 4.12 & 2012 & Direct measurement & $60 \mathrm{~min}$ \\
\hline 15 & $\begin{array}{l}\text { Compensation reservoir } \\
\text { Enzingerboden }\end{array}$ & 3.58 & 63.42 & 1787 & No/insufficient data & $\mathrm{N} / \mathrm{A}$ \\
\hline 16 & Wiegenbach & 2.03 & 2.03 & 1897 & No/insufficient data & $\mathrm{N} / \mathrm{A}$ \\
\hline 17 & Oedbach & 20.25 & 20.25 & 1977 & Direct measurement & $60 \mathrm{~min}$ \\
\hline 18 & Schneiderau & 11.27 & 96.96 & 1833 & Secondary information & $60 \mathrm{~min}$ \\
\hline 19 & Schrofenbach & 1.54 & 1.54 & 1660 & No/insufficient data & $\mathrm{N} / \mathrm{A}$ \\
\hline 20 & Resdiual flow section & 42.32 & 42.32 & 1604 & Direct measurement & $60 \mathrm{~min}$ \\
\hline 21 & $\begin{array}{l}\text { Power Station } \\
\text { Uttendorf }\end{array}$ & 0.52 & 141.34 & 1021 & Direct measurement & $60 \mathrm{~min}$ \\
\hline
\end{tabular}

Note: Area $++=$ Accumulated area including diversions 
therefore by snow-accumulation and -melt processes with decreasing significance for lower areas. The natural flow regime cannot be determined due to the human impacts. Nevertheless, on a long-year basis the highest discharge would be expected to be in June during snow melt and the lowest in winter, especially in the higher subbasins. The long-term mean water balance from the Hydrological Atlas of Austria (BMLFUW 2007) for the overall catchment shows a mean annual precipitation of $1614 \mathrm{~mm}$, a mean annual runoff depth of $1331 \mathrm{~mm}$ and an actual catchment evapotranspiration/sublimation of $283 \mathrm{~mm}$ per year.

\subsection{Runoff information}

Discharge is measured at various water intakes and at the outlets of the diversions and reservoirs. Additionally, water levels are measured at the reservoirs and the actual water volume can be calculated through rating curves. Overall, measured time series of discharge and water levels are available at 24 locations with a temporal resolution of 60 minutes (Table 3) for the years 2004 to 2015. The time series partly show missing values due to maintenance works and other measurement problems like breakdowns of the measuring devices especially in winter.

\subsection{Meteorological inputs and other data}

Gridded precipitation and air temperature data from the INCA (Integrated Nowcasting through Comprehensive Analysis) system (Haiden et al. 2011), available from 2003-2015, is used as input. INCA is the meteorological analysis and operational nowcasting application developed and run by the Central Institute for Meteorology and Geodynamics of Austria (ZAMG), providing meteorological parameters at a high temporal (15$60 \mathrm{~min})$ and spatial $\left(1 \mathrm{~km}^{2}\right)$ resolution. It is used for several flood forecasting systems in Austria
(Stanzel et al. 2008; Herrnegger et al. 2018). For the presented study only analysis fields of precipitation and air temperature are available and the INCA nowcasting product will be the model input for the online forecasting system. The temperature analysis fields are derived by a first guess of the used numerical weather prediction model and is then corrected based on observationforecast differences. The precipitation analysis fields are based on interpolated station observations combined with radar data and do not rely on numerical weather model outputs. The method consists of a spatial interpolation of rain gauge values, in which the radar field is used as a spatial structure function. The interpolation reproduces observed temperature and rain gauge values at station locations. In addition, an elevation correction is applied to the whole INCA dataset in order to take topographic effects on rainfall into account (Haiden and Pistotnik 2009). Rainfall radar information is however limited in the study area as a result of shading effects due to the high elevations and therefore errors in the precipitation amount and distribution can occur, especially in winter (Haiden et al. 2011).

Apart from the INCA air temperature data, the high resolution $\left(1 \mathrm{~km}^{2}\right)$ mean monthly temperatures from the ECSN/HRT-GAR-project (Hiebl et al. 2009) are used as inputs for the calculation of potential evapotranspiration. The reason for using this additional data set is that the availability of the INCA data is limited to the period $2003-2015$. This period would be too short to calculate long-term mean monthly temperature values.

Geospatially referenced snow cover images from the CryoLand database (CryoLand 2017; Malnes et al. 2015), the Copernicus Service for Snow and Land Ice, are used to evaluate the model results concerning snow cover. The data set of the Fractional Snow Cover was obtained from the online databank and pre-processed for the model analysis. The spatial resolution of the product is 250 m (dataset "daily_FSC_Alps_Optical”; period

Table 3 Data availability and type of measurement for the monitored subbasins.

Type of measurement
Water level
Discharge - diversions
Discharge - water intakes
Discharge - reservoir outflows
Discharge - streams/rivers

Subbasins

1 (no rating curve), 5, 6, 8, 12, 13 (no rating curve), 15

Southern diversion ( 1 - 4 \& 9); Northern diversion $(5,6,7)$

$3,4,10,14,17$

$5,6,8$ (outtake \& overflow), $12,15,18$

20, 21 \& one of two streams in 18 
2010-2015) to $500 \mathrm{~m}$ (dataset "daily_FSC_ PanEuropean_Optical"; period 2003-2009) with an estimated accuracy of $15 \%$ at single pixel scale. The change in spatial resolution is a result from the different MODIS product resolutions within the periods, which is used as a basis for CryoLand. Possible inconsistencies due to the change in resolution can be seen as relatively small and therefore negligible since the evaluation is performed on subbasin scale. The pre-processing steps included an extraction of the data for the study area and the subbasins, an exclusion of days with cloud cover and the elimination of the snow in forest and lake mask classes. In a final step, the minimum, maximum and mean snow cover from the CryoLand images was calculated for each individual subbasin.

\section{Methodology}

\subsection{Derivation of local estimated runoff}

Normally, discharge measurements at gauging stations are the main data to calibrate hydrological models for flow forecasting applications (e.g. Stanzel et al. 2008, Schulz et al. 2016). Although these discharge measurements involve some uncertainties (McMillan et al. 2010) they can be directly used to evaluate the model performance through the calculation of objective model performance criteria. In the present study this type of data is only available in three subbasins (see Table 3 Discharge - river). Therefore, a method was developed to derive runoff time series from the secondary measurement series for most of the subbasins. The local or natural runoff of a single subbasin is hereby defined as the flow that is generated in each subbasin individually without any incoming diversions. In case of the reservoirs, the local flow is generated by formulating the water-mass-balance in the subbasin. This is done by calculating the change in volume from the change in water level with a rating curve and further subtracting the inflows and adding the outflows. An example for the calculation is given for subbasin 8 in Figure 2 and equation 1. Similar formulations can be derived for subbasins 5, 6 and 12 (Table 2, Table 3). Losses due to evaporation and infiltration are estimated to be lower than $2 \%$ of the mean discharge and are therefore neglected.

$$
\begin{aligned}
Q_{\text {local }}= & \Delta V(W)+Q_{\text {outflow }}+Q_{\text {overflow }} \\
& -Q_{\mathrm{N} \text {-diversion }}
\end{aligned}
$$

$Q_{\text {local }}: \quad$ local estimated runoff

$\Delta V(W)$ : change in stored water volume due to change in water level

$Q_{\text {outflow: }}$ outflow of the reservoir

$Q_{\text {overflow: }}$ overflow of the reservoir at maximum fill level

$Q_{\mathrm{N}-\text { diversion}}:$ incoming discharge from the northern diversion

Small changes in water levels can lead to large differences in the calculated stored water volumes,

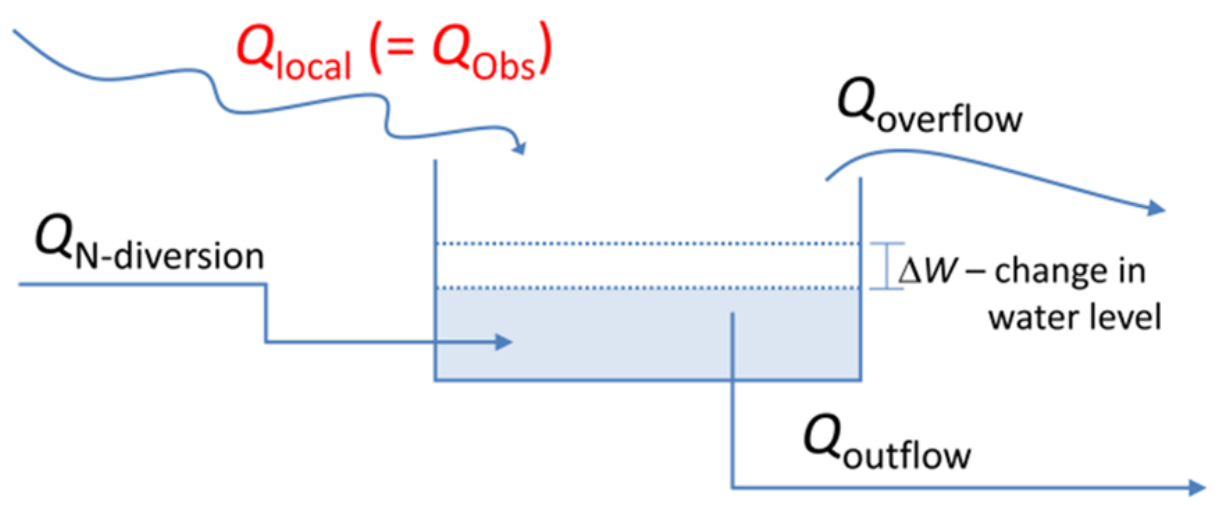

Figure 2 Estimation of the local runoff for subbasin 8 on the basis of water level changes in the reservoir and consideration of other measured flows. $Q_{\text {local }} / Q_{\mathrm{obs}}$ is the estimated local discharge; $Q_{\mathrm{N} \text {-diversion }}$ is the incoming discharge

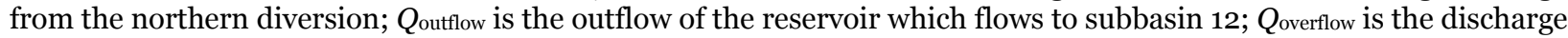
exiting via the overflow of the reservoir at maximum fill level; $\Delta W$ is the change in water level. 
leading to unrealistic delineated local discharges. This is mainly caused by fluctuation or noise in the water level measurements that could originate from wind and wave influence or measurement device sensitivity. Therefore, the original $60-\mathrm{min}$ data are filtered by calculating daily mean values for these subbasins. Figure 3 illustrates the noisy 60-min data compared to the finally used daily time series. Although information about short-term peak discharges and daily fluctuations is lost through the aggregation procedure, systematic errors are eliminated. The $24 \mathrm{~h}$ data remain a good estimation for the local runoff, since no other runoff data is available.

For subbasins 10, 14 and 17, with water intake structures at the outlets, discharge measurements exist. In subbasins 20 \& 21 discharge observations in the rivers exist. In these cases the available time series are used directly. However, due to its design the water intake and therefore the discharge measurements in subbasin 17 are limited to a threshold of $3 \mathrm{~m}^{3} / \mathrm{s}$. Higher discharge flows into subbasin 20 on its natural path and is not observed within the subbasin.

The northern diversion drains subbasins 5 to 7 and is measured at its outlet. Since local runoff has been determined for subbasins 5 and 6 based on water level measurements in the reservoirs Amersee and Salzplattensee and the measured outflow, the local discharge in subbasin 7 is approximated by subtracting these from the daily mean discharge observed at the diversion outlet.

The southern diversion is also measured at its outlet in basin 12. It combines the runoff from subbasins 1 to 4 and 9. Also, sporadic discharge measurements at the water intakes of subbasins 3 and 4 exist. Therefore, two approaches to determine the local runoff can be defined: (i) In case no measurements at the water intakes of subbasins 3 and 4 are available, area weighted proportions of the total diversion discharge is used for each subbasin. (ii) If measurements at water intake 3 and/or 4 exist, the direct measurements are used for these subbasins. For the remaining subbasins area weighted proportions of total diversion discharge excluding the water intakes of 3 and/or 4 are considered. Since the water intake and the diversion discharge measurements are performed at different locations, the water travelling times within the diversion have to be considered. This is done by calculating the 12hourly mean value of the discharge, since it can be assumed that flow time is negligible at this temporal aggregation level.

Subbasin 18 is again a special case, since only part of the catchment discharge is monitored. As an approximation of the local discharge, the observed time series is multiplied by the ratio of the observed catchment area and the total catchment area, resulting in a multiplication factor of 1.86. An overview of the local observed runoff origin and the temporal resolution for all subcatchments is given in Table 1 .

Based on the above approaches, a unique discharge data set is generated for very small highalpine catchments, with the smallest discharge information available for an area of $0.40 \mathrm{~km}^{2}$. It is clear that uncertainties in the data exist and that the uncertainties are larger compared to conventional discharge measurements. Nevertheless,

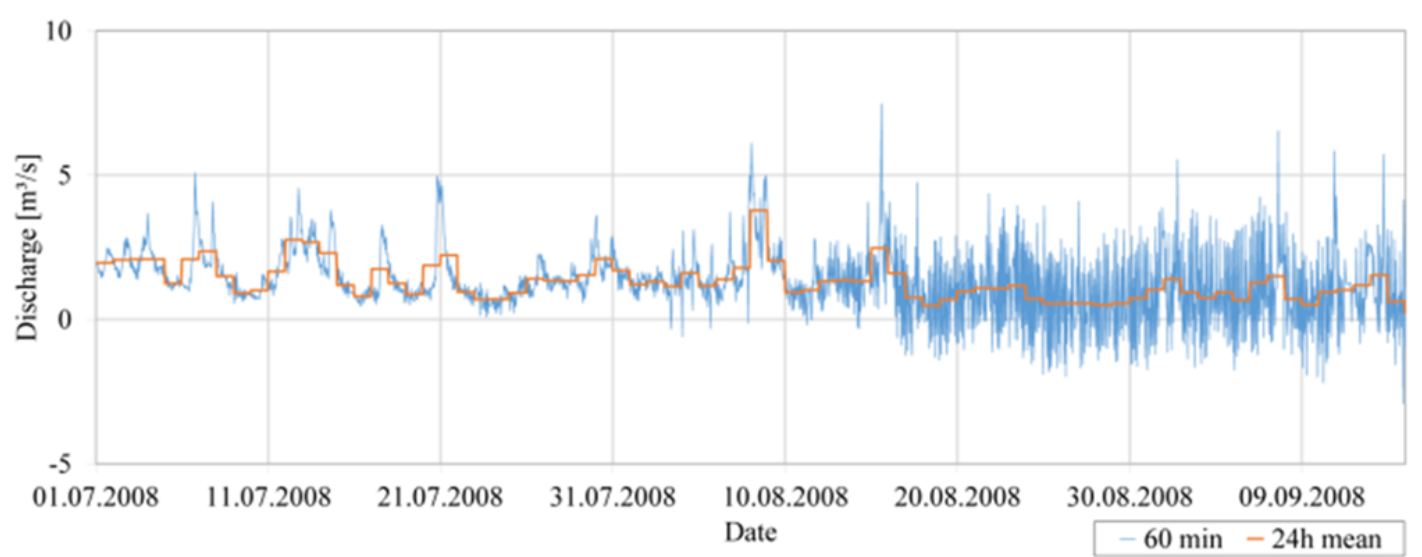

Figure 3 Calculated observed local runoff for subbasin 8 for direct 6o-minute calculation (blue) and the 24 h-mean (orange) in $\mathrm{m}^{3} / \mathrm{s}$. 
for the calibration of the model not only discharge data of the catchment outlet is available but also for many subbasins.

\subsection{Rainfall-runoff model}

The hydrological simulations are performed with the conceptual rainfall-runoff model COSERO (COntinuous SEmidistributed RunOff Model; Eder et al. 2005; Herrnegger et al. 2018, 2015, 2012; Kling and Nachtnebel 2009; Kling et al. 2015; among others), which in its structure is similar to the HBV model (Hydrologiska Byråns Vattenbalansavdelning model, Bergström 1995). The spatial discretization of the model in this study is based on a $250 \mathrm{~m} \times 250 \mathrm{~m}$ grid where geographically connected grid cells with similar characteristics (subbasin, land use, elevation class, hydrogeology and soil type) are merged resulting in 791 calculation zones. Runoff from the single calculation zones within a sub-catchment is routed to the catchment outlet to form the simulated runoff. As driving forces, spatially distributed datasets of temperature and precipitation are used. For the presented application, potential evapotranspiration input is calculated according to the Thornthwaite method (Thornthwaite and Mather 1957). The hydrological model consists of different modules for calculating the processes of snow accumulation and snow melt (Frey and Holzmann 2015), glacier melt (Hock 1999; Nachtnebel et al. 2009), interception storage, evolution of soil moisture, actual evapotranspiration, surface runoff, interflow, base flow and zone to zone routing. A detailed description of the model, including some previous applications and model equations, can be found in Kling et al. (2015).

\subsection{Simulation periods, parameter estimation and evaluation}

The period 01.09.2004-31.08.2012 (8 hydrological years) is used for parameter calibration, with the months January 2003 to August 2004 as spin-up time. The period 01.09.2012 - 31.08.2015 (3 hydrological years) is used for validation of the model performance. This split sample ensures, that we have both wet and dry years in both data sets and can evaluate the overall performance of the model independently from the characteristics of single years (Daggupati et al. 2015). Hydrological years are defined from September to August since the catchment is highly influenced by snow and glacier processes. With this assumption, it can be assumed that the analysis of the water balance is not severely influenced by large amounts of water stored in the model states (Herrnegger et al. 2018). The rainfall-runoff model is run with hourly time steps.

The parameter calibration has been performed in several steps. At first, a "default" parameter set was defined based on values from literature (Kling et al. 2006; Hiebl et al. 2009; Herrnegger et al. 2012; Eder et al. 2003) and from previous COSERO applications (e.g. Stanzel et al. 2008, Schulz et al. 2016). Most of the default parameter fields are spatially distributed and are based on the characteristics (land use, elevation class, hydrogeology and soil type) of the 791 modelling zones. In order to define parameter bounds for the given catchment, an initial manual calibration was performed changing the most influential parameters from the snow and the runoff modules (surface runoff, interflow, base flow). In a further step, including the information on the parameter bounds, a numerical parameter optimisation was performed using the DDS method (Dynamically Dimensioned Search; Tolson and Shoemaker 2007). In order to preserve the spatial pattern of the parameter values, each initial parameter field was adjusted uniformly with one multiplicative factor for the whole catchment. In consequence, a consistent parameter field, without abrupt parameter value changes at catchment boundaries, is guaranteed. Based on the work of Burgholzer (2017), a multi objective approach with 1500 iterations was used. Thereby, each subbasin with local runoff observation was given the same share of the overall objective function. In 11 representative subbasins this was a combination of the Nash-Sutcliffe Efficiency (Nash and Sutcliffe 1970) with a weight of $85 \%$ and the PeakDifference Coefficient (Burgholzer 2017) with a weight of $15 \%$ in order to consider high flow events. In the remaining subbasins only the NSE was used with 100\%. This setup proved best for these catchments. Additionally, the Kling-Gupta Efficiency (Gupta et al. 2009) and the Pearson's correlation coefficient were calculated as additional 
objective criteria to further analyze the strengths and weaknesses of the parameter set. For the evaluation of the model performance, the simulated discharge was aggregated to the same temporal resolution as the runoff observations. The objective criteria are defined as follows:

$$
\mathrm{NSE}=1-\frac{\sum_{t=1}^{n}\left(Q_{s i m, t}-Q_{o b s, t}\right)^{2}}{\sum_{t=1}^{n}\left(Q_{o b s, t}-\overline{Q_{o b s}}\right)^{2}}
$$

NSE Nash-Sutcliffe-Efficiency

$n \quad$ Total number of time-steps

$Q_{\text {sim,t }} / Q_{\text {obs,t }}$ Simulated and observed runoff at time step $t$

$\overline{Q_{o b s}} \quad$ Mean of observed runoff

$$
\text { PDIFF }=1-\frac{\sum_{t=1}^{x}\left(Q_{s i m, t, h}-Q_{o b s, t, h}\right)^{2}}{\sum_{t=1}^{x}\left(Q_{o b s, t, h}-\overline{Q_{o b s}}\right)^{2}}
$$

PDIFF Peak difference coefficient

\section{$x \quad$ Number of events to evaluate [-]}

$h \quad$ Event window radius [h]

$Q_{\text {sim }, t, h} / Q_{o b s, t, h}$ Maximum simulated and observed runoff at time step $\mathrm{t}$ within the event radius $h$

KGE

$$
=1-\sqrt{(r-1)^{2}+\left(\frac{\sigma_{s i m}}{\sigma_{o b s}}-1\right)^{2}+\left(\frac{\overline{Q_{s l m, t}}}{\overline{Q_{o b s, t}}}-1\right)^{2}}
$$

\section{KGE Kling-Gupta-Efficiency}

$\mathrm{r}$ Pearson's Correlation

$\sigma \quad$ Standard deviation

$\overline{Q_{s i m, t}} / \overline{Q_{o b s, t}} \quad$ Mean of simulated/observed runoff Initial automatic calibration results demonstrated that in addition to the standard model set a simplified snow transport module based on Frey and Holzmann (2015) has to be implemented in order eliminate the problem of snow accumulation in high regions - a typical problem with day-degree methods.

Additionally, deficits in stream flow simulations was visible at the catchment outlet. Since evapotranspiration rates are in the same magnitude as presented in the Hydrological Atlas of Austria (see chapter 1.1), it is apparent that the catchment rainfall is not able to reproduce the measured observed discharge sum. These deficits are a well-known phenomenon of the precipitation data in the Central Austrian Alps and have been investigated e.g. by Herrnegger et al. (2015, 2018). Based on these studies, a simple precipitation correction was performed for the northern subbasins $(5-21)$. The long-term water balance deficit indicated that a precipitation increase by $5 \%$ is necessary to compensate the possible measurement errors and possible errors originating from the regionalisation methods. The southern diversion showed better simulation results on a long-term basis, leading to no precipitation correction in these areas.

Furthermore, the automatic calibration procedures highlighted the following problem: The different temporal resolutions of the simulation (6omin) and the majority of the runoff observations (12h/24h temporal resolution) resulted in differences in the short-term temporal dynamics (e.g. diurnal snow melt dynamics; see also Figure 4). Therefore, an additional manual adaption of selected parameters (snow processes, fast flow response) was subsequently performed. Naturally, this resulted in a deterioration of the objective function values but lead to more plausible

Subbasin $3-$ Observed runoff $—$ Simulated runoff (hourly)

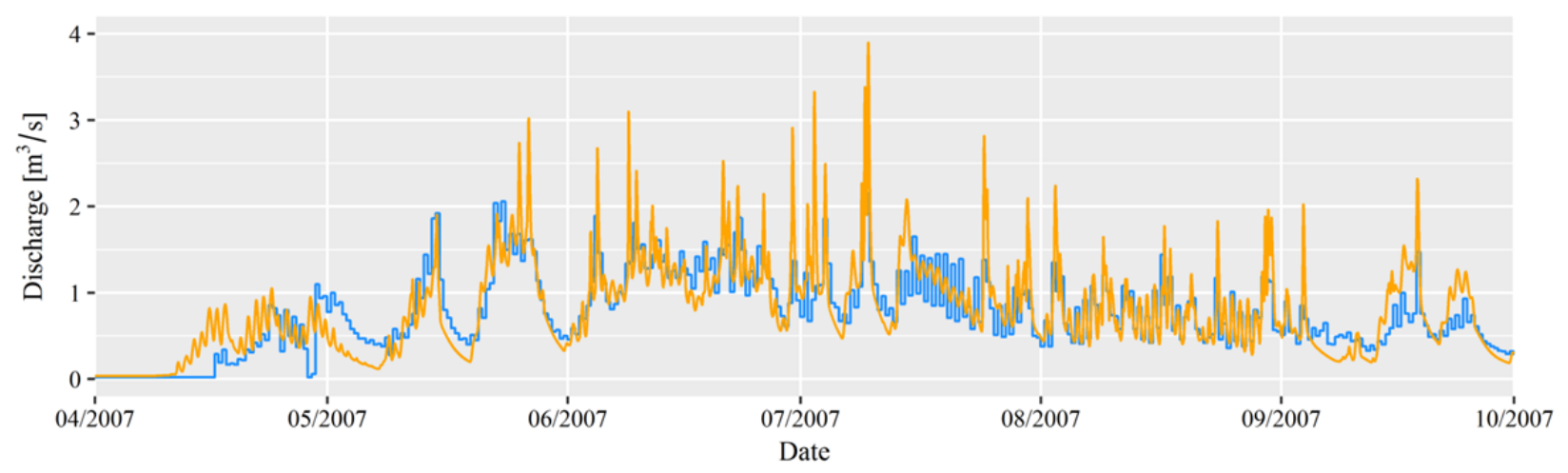

Figure 4 Simulated (6o minute resolution) and observed runoff for subbasin 3 for the summer half-year 2007. 
simulated discharge patterns and system states.

\section{Results}

With the final parameter set of the calibration, the COSERO model can be run for both the calibration and the validation period. As a result, the model not only provides the discharge simulations for each subbasin but also information on other fluxes and states (e.g. soil moisture, snow cover etc.). Therefore, different parts of the water balance or the snow cover can be analysed in detail to further evaluate the model results.

\subsection{Rainfall-Runoff simulations}

Hydrographs of the simulated discharge are available for all 21 subbasins, but comparison and quality analysis is only possible in 15 subbasins, where observed discharge is available or was derived (Table 3). In order to illustrate the unique nature of the observed data, Figure 4 shows the hydrographs (blue $=$ observed, orange $=$ simulated) for basin 3 in the summer half of the year 2007 . The stepwise structure of the observation can be explained by the 12-hourly averaging process applied in basin 3 as described in the methods section. In order to compare the hydrographs, the simulation was aggregated to the same temporal resolution as the observation (Figure 5). By comparing the two simulated hydrographs it can be seen that they are very similar and, only during short and high peaks, the aggregated simulation is more damped. Overall, these illustrations show that mostly very good results are obtained with the calibrated model. Although the beginning of the snow melt is simulated too early in the model in the year 2007, other observed dynamics are well captured in the simulations. Similar results are found for the other subbasins. Nevertheless, in catchments with glaciers, the transition from snow melt to glacier melt can cause problems in some years as it can be seen in July 2007 in Figure 4.

The model performance calculated with the temporally aggregated simulations is presented in Table 4 for each analysed basin for the calibration and the validation period. For the latter period, no observed local flow is available for subbasins 1, 2, 9 and 18.

The overall performance in the calibration period is quite satisfactory with NSE values above

Table 4 Nash-Sutcliffe Efficiency (NSE), Kling-Gupta Efficiency (KGE) and Pearson's Correlation (r) for the different periods and subbasins calculated with Eq. (2) and Eq. (3). Not available (N/A) values result from missing data.

\begin{tabular}{|l|l|l|l|l|l|l|}
\hline $\begin{array}{l}\text { Sub- } \\
\text { basin }\end{array}$ & \multicolumn{2}{|l}{ Calibration } & \multicolumn{3}{l}{ Validation } \\
\hline 1 & 0.74 & 0.80 & 0.78 & N/A & N/A & N/A \\
\hline 2 & 0.45 & 0.72 & 0.71 & N/A & N/A & N/A \\
\hline 3 & 0.78 & 0.85 & 0.76 & 0.79 & 0.79 & 0.85 \\
\hline 4 & 0.67 & 0.78 & 0.72 & 0.66 & 0.73 & 0.73 \\
\hline 5 & 0.78 & 0.74 & 0.77 & 0.54 & 0.43 & 0.81 \\
\hline 6 & 0.69 & 0.64 & 0.72 & 0.57 & 0.43 & 0.76 \\
\hline 7 & 0.76 & 0.82 & 0.76 & 0.61 & 0.62 & 0.85 \\
\hline 8 & 0.64 & 0.52 & 0.72 & 0.59 & 0.47 & 0.87 \\
\hline 9 & 0.71 & 0.80 & 0.69 & N/A & N/A & N/A \\
\hline 10 & 0.55 & 0.43 & 0.74 & 0.25 & 0.07 & 0.85 \\
\hline 12 & 0.69 & 0.78 & 0.78 & 0.63 & 0.62 & 0.87 \\
\hline 14 & 0.56 & 0.68 & 0.70 & 0.59 & 0.79 & 0.67 \\
\hline 17 & 0.58 & 0.71 & 0.60 & 0.59 & 0.74 & 0.81 \\
\hline 18 & 0.48 & 0.60 & 0.56 & N/A & N/A & N/A \\
\hline 20 & 0.52 & 0.75 & 0.61 & 0.44 & 0.71 & 0.63 \\
\hline
\end{tabular}

Subbasin $3-$ Observed runoff - Simulated runoff (aggregated - 12h)

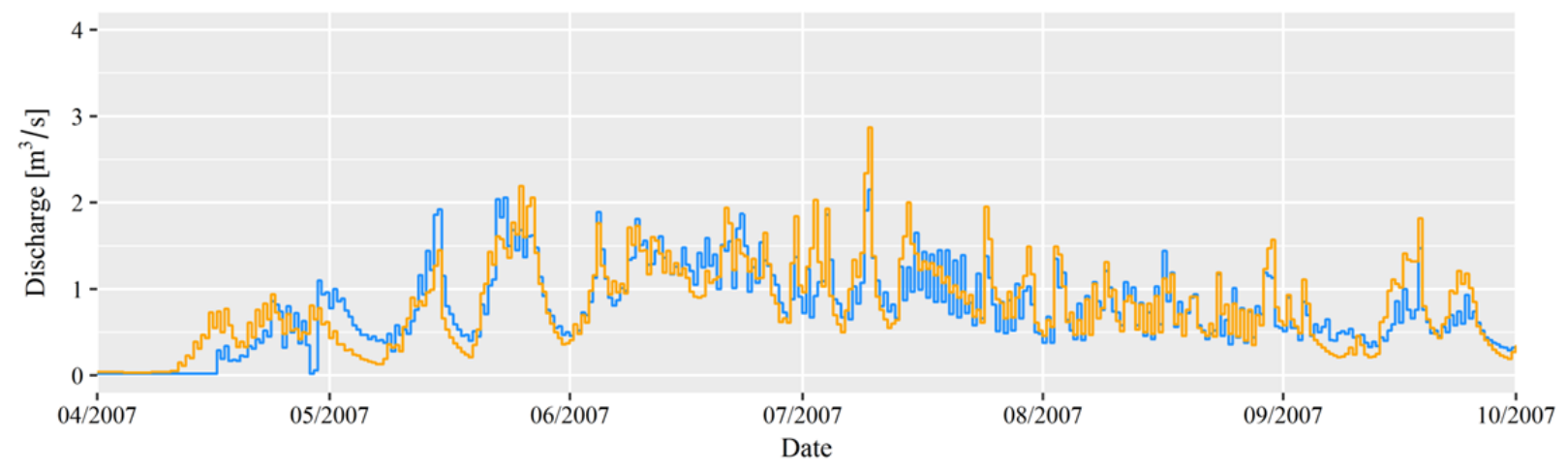

Figure 5 Simulated runoff (12-h mean) and observed discharge for subbasin 3 for the summer half-year 2007. 
0.5 for most of the subbasins and a maximum of 0.78 in subbasin 3 . In addition, the other objective functions KGE and the Correlation show similar good results. This is especially true, bearing in mind the demanding high-alpine setting and that the observed discharge values are not available through direct measurement but through calculation. Therefore they are also influenced by errors such as occasional lack of data or biased measurements e.g. due to sedimentation at the water intake structures. Additionally, homogenous parameter fields derived in this study always result in lower values of the objective functions compared to a basin-by-basin calibration procedure.

The simulations in the validation period also show satisfactory results for the majority of the subbasins. Only subbasin 10 and the subbasins of the northern diversion $(5,6,7)$ show noticeable deterioration in the performance. Since the calculated observed discharge of the latter subbasins highly depend on each other and all show similar tendencies, the deterioration of model performance could be connected to deficits in the input data, namely precipitation. In Figure 6 the results of subbasin 5 for the validation year 2015 with aggregated simulated discharge is shown. The beginning of the snow melt season is well captured, followed by a significant underestimation of the observations in June and July. Assuming that the derived runoff observations show reality, it seems that too little precipitation (also in form of snow in the winter season) is available as input in the model. Similar patterns are evident in the subbasins 6 and 7. In order to further analyse these underestimations, the water balance components are evaluated in chapter 3.2.

\subsection{Seasonal water balance and water balance component analysis}

In order to analyse the correct timing of the hydrological processes, such as snowmelt and high flow periods, the mean monthly discharge rates for the calibration period have been analysed for the subbasins and representative results are shown in Figure 7. Generally, the seasonality in the observed runoff is well represented by the simulation. In subbasin 12, containing the main reservoir Tauernmoossee, the simulated discharge follows the observed seasonality but is lower compared to the observations. The derivation of local runoff in winter months for this subbasin always showed unrealistic high values and was obviously erroneous. One of the secondary information needed to calculate the local runoff seems to be wrong, e.g. due to measurement errors resulting from icing. It is however not clear, what the exact cause for this behaviour is. The winter months are therefore excluded. The simulated seasonality in subbasin 5, which contains a smaller reservoir (Amersee), also follows the observation, although the distinct summer peak is underestimated in the simulation. In the other catchments, simulation and observation match very well. Additionally, timing and magnitude of the snowmelt during April and May is well reproduced.

The simulations of the other components of the water balance (precipitation, evapotranspiration, glacier melt and discharge) is further analysed to examine the plausibility of the model runs.

Subbasin $5-$ Observed runoff - Simulated runoff (aggregated - 24h)

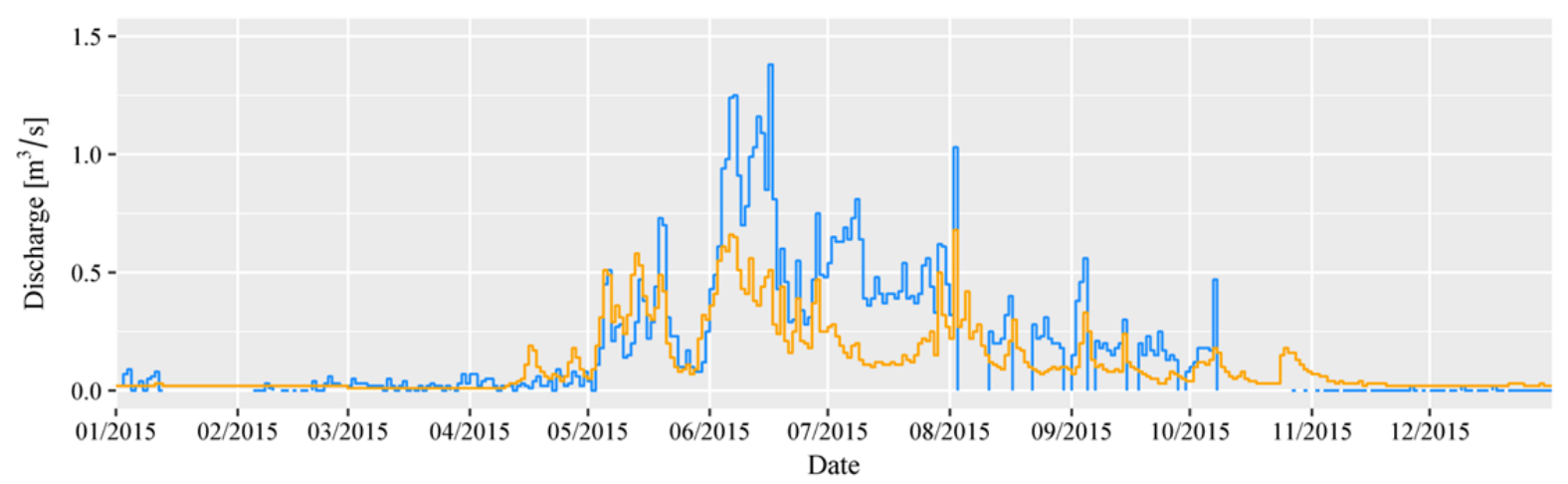

Figure 6 Simulated and observed discharge for subbasin 5 for the validation year 2015 showing the underestimation of the observation in June and July. 
Subbasin 5 shows a significant deterioration of model performance in the validation period (Table 4; Figure 6). Figure 8 therefore presents the water balance components for subbasin 5 for both the calibration and the validation period. In the calibration period, the simulated discharge (orange) and the observed discharge (blue) mostly follow the precipitation pattern (green) very well, although the interannual variability is higher in the simulations. The evapotranspiration (red) and the glacier melt (light blue) in comparison do not fluctuate strongly during the different hydrological years. Although glacier melt measurements are potentially available for Stubacher Sonnblick Kees located in subbasin 8 , the time series could not be acquired for this study. The magnitude of the glacier melt simulations however seem realistic. The actual evapotranspiration simulations are also in the scale published in BMLFUW (2007).

For the validation period, the observed discharge (blue) is significantly larger compared to the precipitation and the simulated discharge. Additionally, the observed discharge is also increasing during a period with precipitation
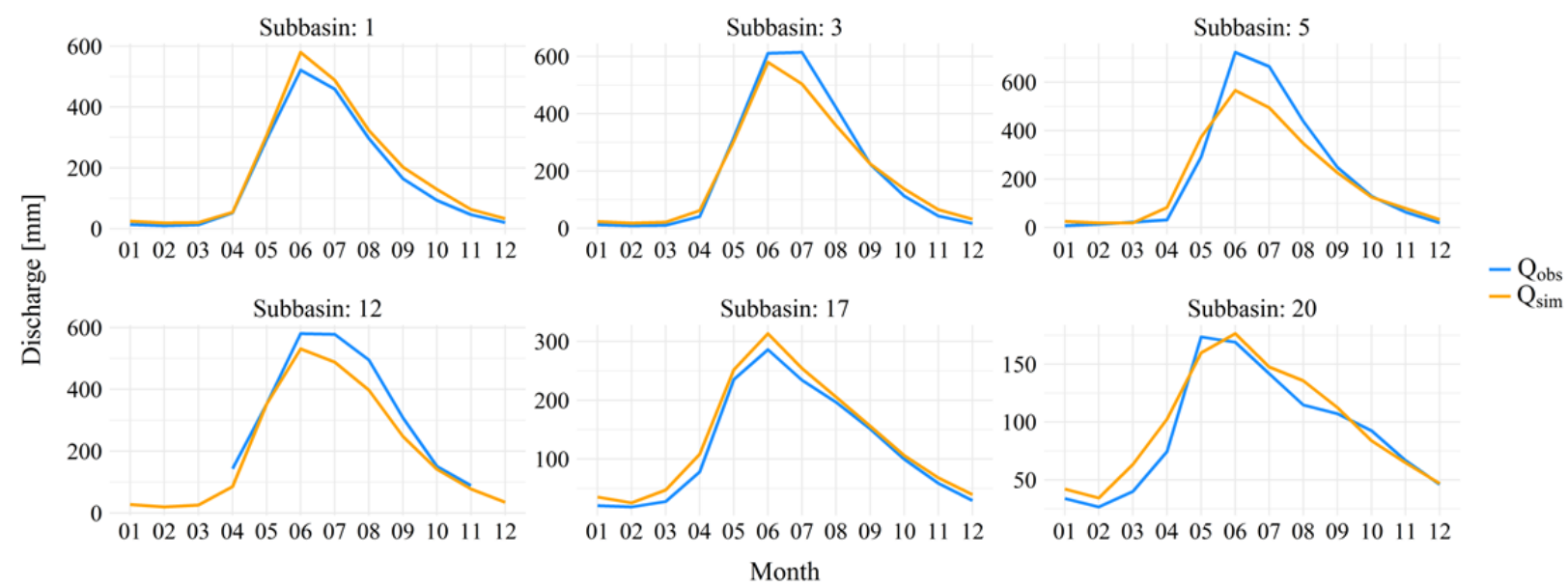

Figure 7 Mean monthly discharge depth for observation $\left(Q_{\mathrm{obs}}\right)$ and simulation $\left(Q_{\text {sim }}\right)$ for the calibration period for selected subbasins.

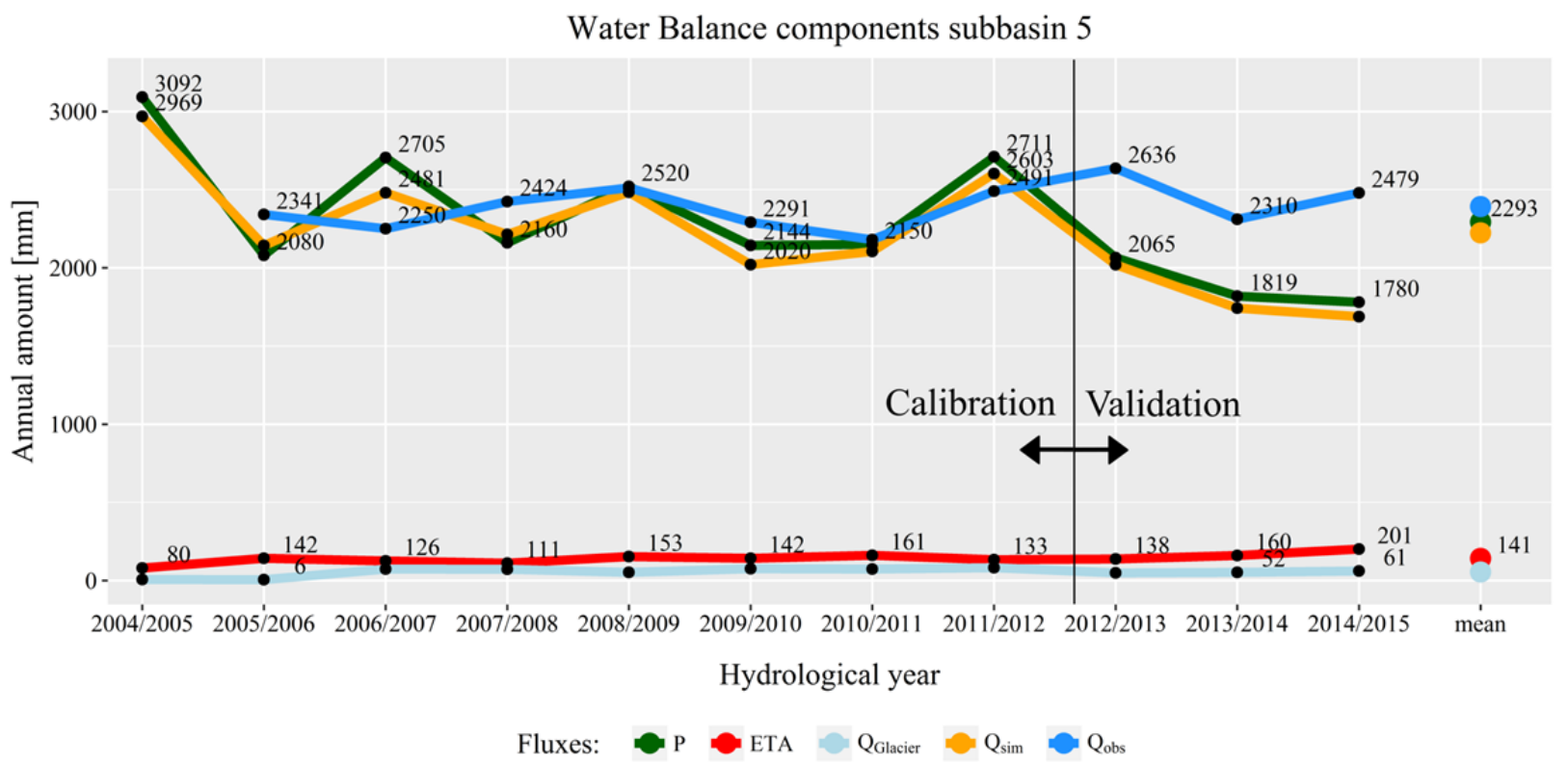

Figure 8 Simulated water balance components and calculated observed discharge for subbasin 5 for the hydrological years of the calibration and validation period. The numbers displayed are the annual amounts in mm for the corresponding component at the marked point. For overlapping points, only one value is displayed for enhanced readability. $\left(\mathrm{P}=\right.$ Precipitation, ETA $=$ Actual Evapotranspiration, $Q_{\text {Glacier }}=$ runoff from glacier, $Q_{\text {sim }}=$ simulated runoff, $Q_{\mathrm{obs}}=$ estimated local runoff) 
decline. The deviations in the validation period could be explained by either errors in the derived discharge data or from a significant underestimation of the precipitation input. In both cases additional information would be necessary for deeper investigations. Independent precipitation observations not used in the generation of the gridded INCA data could for example shed light on this issue.

\subsection{Snow cover}

The simulation of snow cover and in consequence the water stored in the snow layer (snow water equivalent, SWE) are important in the context of an inflow prediction system for a hydropower scheme in the Alps. The knowledge of SWE stored is relevant for managing the reservoirs, since the snowmelt is used to replenish the reservoirs, which normally show low water levels at the end of the winter season / beginning of spring.

In the Stubache valley, snow accumulation and melting processes as well as glacier melt play an important role since $52 \%$ of the precipitation is snow. Therefore, the modelling results of the snow module of COSERO are analyzed in more detail by comparing the simulated snow cover with data from the CryoLand database. Figure 9 shows the simulated continuous COSERO snow cover data in comparison to the CryoLand snow cover for subbasin 4 and subbasin 17 for two different years with a sufficient number of CryoLand snow cover images. It can be seen that the snow cover distribution of the two sources mostly match well although COSERO is frequently at the upper end (maximum) of the snow cover of the CryoLand data. The beginning of the snow cover reduction in spring differs in the two subbasins due to their different elevations. It is also visible, that COSERO tends to show a slower reduction in snow cover compared to the remote sensing data in spring. However, studies (e.g. Parajka and Blöschl 2006) also show that the satellite derived data often underestimates snow cover in spring.

\section{Discussion}

The setup of hydrological models for inflow prediction for high-alpine hydropower schemes is challenging when considering the typical setting. The schemes include a multifaceted system of water intake structures, transport lines with frequent diversions from other catchments and possibly consist of several interconnected

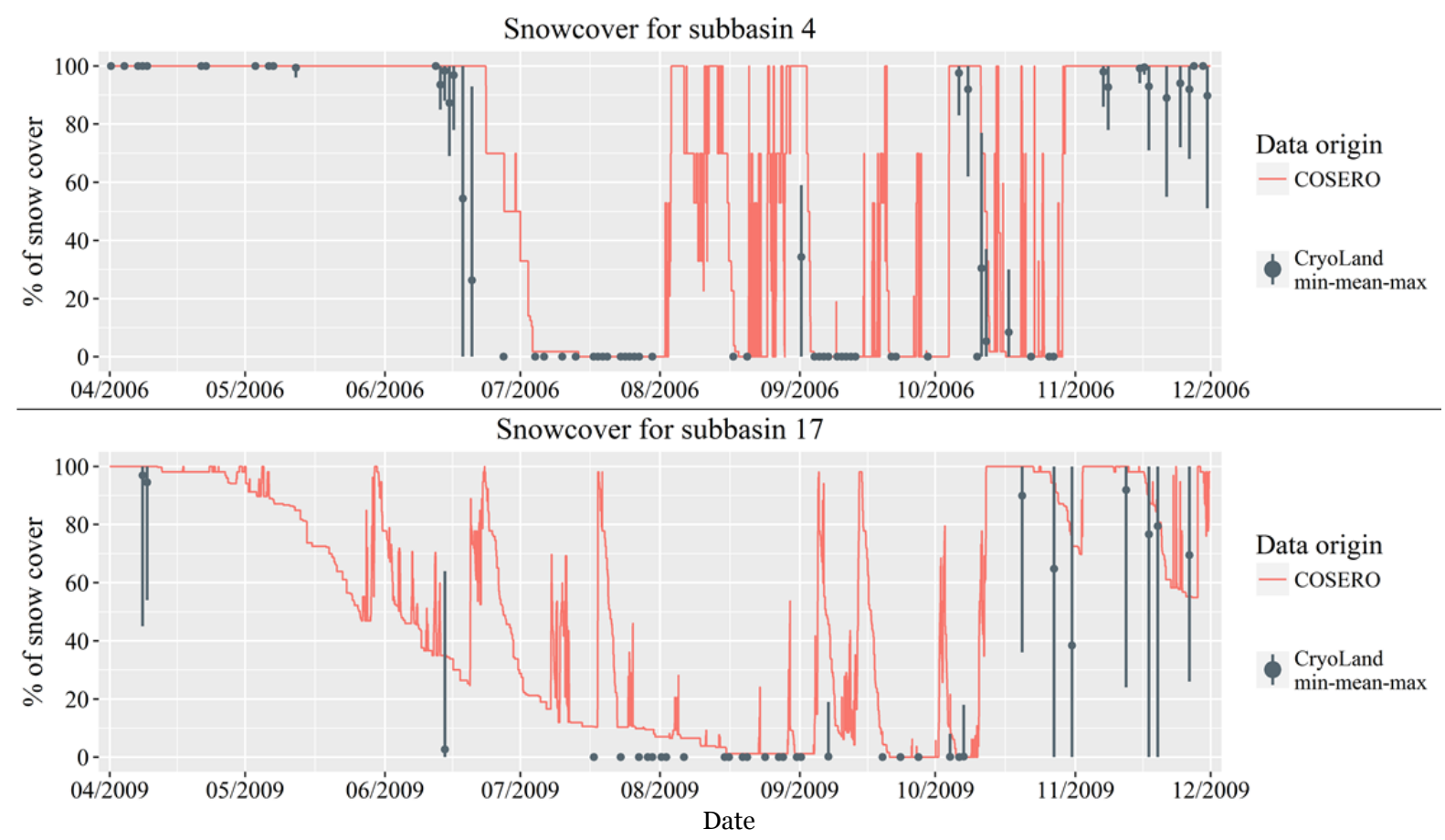

Figure 9 Comparison of the COSERO snow cover (red) and the (cloud-free) CryoLand mean (black point) and minimal/maximal (black line) snow cover for subbasin 4 (top) and subbasin 17 (bottom). 
reservoirs and hydropower stations. The natural topography is complex, with large elevation differences and steep gradients. The catchments are characterised by different vegetation zones, ranging from the montane, subalpine and alpine to the nival zone. The land cover in consequence typically consists of mixed and conifer forests, alpine meadows and sparse or no vegetation on the mountain ridges and glaciers. The hydrology is partly not well understood and complex, since different hydrological processes (e.g. glacier and snowmelt, runoff from rainfall) interact with each other and are not measured in detail. Additionally, the hydrology is massively influenced by the human activity.

The necessity to manage such a system in an optimal way with an inflow prediction system requires a compromise between representing the physical/hydrological system in its functional details and the necessity of fast calculations within an operational setting. With its conceptual model structure, COSERO is able to represent the most important processes in the catchment using the historical INCA data for calibration and meteorological forecasts for the online system with comparably low calculation times. With this concept, the spatial resolution of $250 \mathrm{~m} \times 250 \mathrm{~m}$ is sufficient since many subgrid processes are represented within the model. In this study, the input data available from the meteorological models is limited to temperature and precipitation for the forecasting system. Therefore, the applied calculation methods are also limited to the available data sets. The snow module, with its degree-day snow melt method, for example only needs temperature as input. It is clear that the degree-day method does not represent snow melt processes in detail as has been discussed in the hydrological community (e.g. Bernhardt et al. 2009; Brubaker et al. 1996; Rutter et al. 2009). However, to simulate these processes in more detail additional meteorological parameters like wind speed or solar radiation would be needed in order to apply a model comparable to the one used in Achleitner et al. (2012). Nevertheless, this data is not available for the developed online forecasting system. Additionally, these methods are often only applicable for a limited (small) area. Snow processes like snow canopy interactions as described by Strasser (2011) are not directly considered within COSERO. Nevertheless, the degree-day method included in COSERO is more complex than in other HBV type models since it considers processes like cold content and uses a lognormal snow distribution on the subgrid scale (Frey and Holzmann 2015). Hock (2003) mentions all the shortcomings of temperature index methods but also emphasizes their applicability for hydrological modelling knowing its limitations. Bearing that in mind, the snow modelling results of COSERO are sufficiently exact for the prediction of the stream flow in the study area.

Generally, the results of the model performance must also be seen in the light of the challenging high-alpine setting of the study area and the simulation of very small catchment areas. Simulating the runoff of a larger river, given adequate inputs, will always be easier, compared to the simulation of a small creek. The estimation of the driving inputs, for example, is difficult on small scales due to high spatio-temporal variability, which is especially true for the high alpine environment. Non-linear hydrological processes, which may be very distinct in a small area and which tend to be difficult to simulate, are averaged out when modelling larger areas. Many of the presented catchments have a very small catchment area. For example, subbasin 5, 6 and 7 cover an area of 2.2., 0.52 and $1.85 \mathrm{~km}^{2}$. Accordingly, low discharge values are observed. Subbasin 5, 6 and 7, for example, have a mean discharge of only $217 \mathrm{~L} / \mathrm{s}$, $48 \mathrm{~L} / \mathrm{s}$ and $175 \mathrm{~L} / \mathrm{s}$, respectively.

The initial, uncalibrated parameter set, which is based on the catchment characteristics, already produced quite satisfying results, with NSE values up to 0.7 for some subbasins. Therefore, it is assumable that a direct transfer of the parameters to similar catchments nearby may be valid and the rainfall-runoff model COSERO could be applied in other small high-alpine catchments and, to some extent, substitute missing discharge time series. Certainly, this approach can only be seen as a first guess in ungauged basins but can be used for feasibility studies and other engineering applications. In Parajka et al. (2013) a framework for this method is presented, highlighting the importance of a rational choice of parameter transfer method. The authors justify this saying that the approach is that if two catchments are similar in their catchment characteristics one 
would hope that their hydrological response should be similar too, so the model parameter values should be similar.

\section{Summary and Conclusions}

For the management of reservoir water levels and hydropower production in high alpine hydropower schemes, hydrological forecasting models can provide valuable and objective information for decision makers. The hydrological modelling in high alpine areas is however challenging. Often, only limited data exists to set up a rainfall-runoff model that can be used for local flow predictions. The rainfall-runoff model COSERO was set up successfully for the Stubache catchment in the Central Austrian Alps. It consists of seven reservoirs, four main power stations and several water diversions that transport water from adjacent catchment areas. Here, a method was developed to derive local runoff from secondary flow information such as reservoir outflows and water level measurements. As a result, local discharge has been generated for very small highalpine catchments resulting in a unique runoff dataset used for the calibration of a hydrological model. Additionally, the derived runoff information also shows the spatial variability in runoff for several catchments, which is also in this form unique.

Generally, the model simulations are quite satisfactory with a highest Nash-SutcliffeEfficiency (NSE) of 0.78 (0.79) and a mean NSE of 0.64 (0.57) for the calibration (validation) period. This is especially true having in mind the application of homogenous and consistent parameter fields and the limitations of the derived discharge information. It must also be considered that the subbasin areas are very small, ranging from 0.4 to $42.3 \mathrm{~km}^{2}$ with an altitude range from $790 \mathrm{~m}$ a.s.l to $3450 \mathrm{~m}$ a.s.l. Additionally, the plausibility of the seasonal water balance as well as the annual water balance components was evaluated.

The presented results show that the applied model with the validated parameter set can be used for inflow prediction to the water intakes and the reservoirs. If run with temperature and precipitation forecasts, the model can be integrated in the electricity production management scheme and water transitions can be optimized.

Further improving the simulation performance would require the implementation of more complex modules for representing hydrological processes in more detail in the model. Given the case that the meteorological forecasts of e.g. wind speed, global radiation or relative humidity could be integrated in the required spatio-temporal resolution and quality into COSERO, a more detailed representation of snow and glacier processes would be possible. Currently, the representations is limited to simpler modelling concepts (i.e. degree-day method) since the input data in the operation model is limited to precipitation and temperature. The same also counts for the estimation of potential evapotranspiration, which is currently calculated with the Thornthwaite method and therefore only relies on temperature. Here, the application of the Penman-Monteith method could be an alternative in case appropriate input data is available. Additionally, more advanced calibration methods (e.g. Klotz et al. 2017; Hanzer et al. 2016), could be helpful in parameter estimation and to better represent the snow- and glacio-hydrological components.

\section{Acknowledgments}

This study was funded by the ÖBB Infrastructure. The authors thank ÖBB Infrastructure, namely Markus Wippersberger and Michaela Haberler-Weber, for the financial support and fruitful cooperation enabling this contribution. Open access funding provided by University of Natural Resources and Life Sciences Vienna.

\section{Open Access}

This article is distributed under the terms of the Creative Commons Attribution 4.0 International License (http://creativecommons. org/licenses/by/4.o/), which permits unrestricted use, distribution, and reproduction in any medium, provided you give appropriate credit to the original author(s) and the source, provide a link to the Creative Commons license, and indicate if changes were made. 


\section{References}

Abbott MB, Bathurst JC, Cunge, JA, et al. (1986) An introduction to the European Hydrological System - Systeme Hydrologique Europeen, "SHE", 1: History and philosophy of a physically-based, distributed modelling system. Journal of Hydrology 87: 45-59. https://doi.org/10.1016/o022-1694(86)90114-9

Alpine Convention (1995) Water and Water Management issues - Report on the State of the Alps: Permanent Secretariat of the Alpine convention, Innsbruck, Austria. Available online at:

(http://www.alpconv.org/en/AlpineKnowledge/RSA/water/ Documents/20090625_RSA_II_long.pdf, accessed on : 201706-15)

Achleitner S, Schöber J, Rinderer M, et al. (2012) Analyzing the operational performance of the hydrological models in an alpine flood forecasting system. Journal of Hydrology 412413: 90-100. https://doi.org/10.1016/j.jhydrol.2011.07.047

Bätzing W (1997) Kleines Alpenlexikon: Umwelt, Wirtschaft, Kultur. ISBN: 3406420052/3-406-42005-2

Bergström S (1995) The HBV model. In: Singh VP (ed.), Computer Models of Watershed Hydrology. Water Resources Publications, Highland Ranch, CO, USA. pp 443-476.

Bernhardt M, Zängl G, Liston GE, et al. (2009) Using wind fields from a high resolution atmospheric model for simulating snow dynamics in mountainous terrain. Hydrological Processes 23: 1064-1075. https://doi.org/10.1002/hyp.7208

BMLFUW (2013) Hydrographisches Jahrbuch 2013 (Hydrographic year book 2013). Vienna: Federal Ministry of Agriculture, Forestry, Environment and Water Management. (In German)

BMLFUW (2007) Hydrological Atlas of Austria. Third Installment. Vienna: Federal Ministry of Agriculture, Forestry, Environment and Water Management. (In German)

Brubaker K, Rango A, Kustas W (1996) Incorporating radiation inputs into the Snowmelt Runoff Model. Hydrological Processes 10: 1329-1343. https://doi.org/10.1002/(SICI)10991085(199610)10:10<1329::AID-HYP464>3.0.CO;2-W

Budyko MI (1974) Climate and Life. New York: Academic Press, p 508.

Burgholzer R (2017) Comparison of manual and automatic Parameter Calibration of the R-R-model COSERO for the Mur catchment. Master thesis, University of Natural Resources and Life Science, Vienna, Austria. p 240.

Čenčur Curk B, Cheval S, Vrhovnik P, et al. (2014) CC-WARE Mitigating Vulnerability of Water Resources under Climate Change. WP3 - Vulnerability of Water Resources in SEE. Report. p82. Available online at:

(http://www.ccware.eu/downloads/external-

downloads/doc_download/396-cc-ware-wp3-report-finalversion.html, accessed on: 2017-06-15)

CryoLand (2017) CryoLand - Copernicus Service Snow and Land Ice. (http://www.cryoland.eu, accessed on: 2017-06-21)

Daggupati P, Pai N, Ale S, et al. (2015) A recommended calibration and validation strategy for hydrologic and water quality models. Transactions of the ASABE 58: 1705-1719. https://doi.org/10.13031/trans.58.10712

de Jong C, List F, Ergenzinger C (2002) Experimental hydrological analyses in the Dischma based on daily and seasonal evaporation. Hydrology Research 33(1): 1-14

Devi KG, Ganasri BP, Dwarakish GS (2015) A Review on Hydrological Model. Aquatic Procedia 4: 1001-1007. https://doi.org/10.1016/j.aqpro.2015.02.126

Duque AJ, Castronuovo ED, Sánchez I, et al. (2011) Optimal operation of a pumped-storage hydro plant that compensates the imbalances of a wind power producer. Electric Power
Systems Research 81: 1767-1777.

https://doi.org/10.1016/j.epsr.2011.04.008

Eder G, Fuchs M, Nachtnebel HP, et al. (2005) Semi-distributed modelling of the monthly water balance in an alpine catchment. Hydrological Processes 19: 2339-2360.

https://doi.org/10.1002/hyp.5888

EEA (2017) Renewable energy in Europe 2017 - Recent growth and knock-on effects. EEA Report No 3/2017. European Environment Agency, Luxembourg: Publications Office of the European Union. p 70. https://doi.org/10.280o/75442

Eurostat (2017) Energy from renewable sources - shares. Dataset code: nrg_ind_335a. Available online at: http://ec.europa.eu/eurostat/web/energy/data/shares (Accessed on 27 June 2017).

Finger D, Pellicciotti F, Konz M, et al. (2011) The value of glacier mass balance, satellite snow cover images, and hourly discharge for improving the performance of a physically based distributed hydrological model. Water Resources Research 47(7). https://doi.org/10.1029/2010WRoo9824

Finger D, Vis M, Huss M, et al. (2015) The value of multiple data set calibration versus model complexity for improving the performance of hydrological models in mountain catchments. Water Resources Research 51: 1939-1958.

https://doi.org/10.1002/2014WR015712.

Frey S, Holzmann H (2015) A conceptual, distributed snow redistribution model. Hydrology and Earth System Science 19: 4517-4530. https://doi.org/10.5194/hess-19-4517-2015

Ghumman AR, Ghazaw YM, Sohail AR, Watanabe K (2011) Runoff forecasting by artificial neural network and conventional model. Alexandria Engineering Journal 50: 345350. https://doi.org/10.1016/j.aqpro.2015.02.126

Gupta HV, Kling H, Yilmaz KK, et al. (2009) Decomposition of the mean squared error and NSE performance criteria: Implications for improving hydrological modelling. Journal of Hydrology 377: 80-91. https://doi.org/10.1016/j.jhydrol.2009.08.003

Härer S, Bernhardt M, Schulz K (2016) PRACTISE - photo rectification and Classification Software (V.2.1). Geoscientific Model Development 9(1): 307-321. https://doi.org/10.5194/gmd-9-307-2016

Haiden T, Kann A, Wittmann C, et al. (2011) The Integrated Nowcasting through Comprehensive Analysis (INCA) System and Its Validation over the Eastern Alpine Region. Weather Forecast 26: 166-183. https://doi.org/10.1175/2010WAF2222451.1

Haiden T, Pistotnik G (2009) Intensity-dependent parameterization of elevation effects in precipitation analysis. Advances in Geoscience 20:33-38. https://doi.org/10.5194/adgeo-20-33-2009

Hamlet AF, Huppert D, Lettenmaier DP (2002) Economic Value of Long-Lead Streamflow Forecasts for Columbia River Hydropower. Journal of Water Resources Planning and Management 128 (2). American Society of Civil Engineers: 91101. https://doi.org/10.1061/(ASCE)0733-9496(2002)128:2(91)

Hanzer F, Helfricht K, Marke T, et al. (2016) Multilevel spatiotemporal validation of snow/ice mass balance and runoff modeling in glacierized catchments. The Cryosphere 10: 1859-1881. https://doi.org/10.5194/tc-10-1859-2016

Hiebl J, Auer I, Böhm R, et al. (2009) A high-resolution 19611990 monthly temperature climatology for the greater Alpine region. Meteorologische Zeitschrift 18: 507-530. https://doi.org/10.1127/0941-2948/2009/0403

Herrnegger M, Nachtnebel HP, Haiden $T$ (2012) Evapotranspiration in high alpine catchments - an important part of the water balance! Hydrology Research 43: 460. https://doi.org/10.2166/nh.2012.132

Herrnegger M, Nachtnebel HP, Schulz K (2015) From runoff to 
rainfall: inverse rainfall-runoff modelling in a high temporal resolution. Hydrology and Earth System Science 19: 46194639. https://doi.org/10.5194/hess-19-4619-2015

Herrnegger M, Senoner T, Nachtnebel HP (2018) Adjustment of spatio-temporal precipitation patterns in a high Alpine environment. Journal of Hydrology 556: 913-921. https://doi.org/10.1016/j.jhydrol.2016.04.068

Hock R (1999) A distributed temperature-index ice- and snowmelt model including potential direct solar radiation. Journal of Glaciology 45(149): 101-111. https://doi.org/10.1017/So022143000003087

Hock R (2003) Temperature index melt modelling in mountain areas. Journal of Hydrology 282: 104-115. https://doi.org/10.1016/Soo22-1694(03)00257-9

Holländer HM, Blume T, Bormann H, et al. (2009) Comparative Predictions of Discharge from an Artificial Catchment (Chicken Creek) Using Sparse Data. Hydrology and Earth System Science 13 (11): 2069-2094. https://doi.org/10.5194/hess-13-2069-2009

Kapsali M, Kaldellis JK (2010) Combining hydro and variable wind power generation by means of pumped-storage under economically viable terms. Applied Energy 87: 3475-3485. https://doi.org/10.1016/j.apenergy.2010.05.026

Kling H, Nachtnebel HP (2009) A method for the regional estimation of runoff separation parameters for hydrological modelling. Journal of Hydrology 364: 163-174. https://doi.org/10.1016/j.jhydrol.2008.10.015

Kling H, Stanzel P, Fuchs M, et al. (2015) Performance of the COSERO precipitation-runoff model under non-stationary conditions in basins with different climates. Hydrological Sciences Journal 60: 1374-1393. https://doi.org/10.1080/02626667.2014.959956

Klotz D, Herrnegger M, Schulz K (2017) Symbolic regression for the estimation of transfer functions of hydrological models. Water Resources Research 53: 9402-9423. https://doi.org/10.1002/2017WR021253

Lang H (1981) Is evaporation an important component in high alpine hydrology? Hydrology Research 12: 217-224

Malnes E, Buanes A, Nagler T, et al. (2015). User requirements for the snow and land ice services - CryoLand, The Cryosphere 9: 1191-1202. https://doi.org/10.5194/tc-9-1191-2015

McGuire M, Wood AW, Hamlet AF, et al. (2006) Use of Satellite Data for Streamflow and Reservoir Storage Forecasts in the Snake River Basin. Journal of Water Resources Planning and Management 132 (2). https://doi.org/10.1061/(ASCE)0733-9496(2006)132:2(97)

McMillan H, Freer J, Pappenberger F, et al. (2010) Impacts of uncertain river flow data on rainfall-runoff model calibration and discharge predictions. Hydrological Processes 24: 12701284. https://doi.org/10.1002/hyp.7587

Nachtnebel HP, Haberl U, Stanzel P, et al. (2009) Hochwasserprognose Salzach - Hydrologische Abflussmodellierung - Teil 3. In: Amt der Salzburger Landesregierung: HydrisII Hydrologisches Informationssystem zur Hochwasservorhersage im Land Salzburg. Amt der Salzburger Landesregierung, 341. (In German)

Nash JE, Sutcliffe JV (1970) River flow forecasting through conceptual models part I - A discussion of principles. Journal of Hydrology 10: 282-290.

https://doi.org/10.1016/0022-1694(70)90255-6
Regonda SK, Rajagopalan B, Clark M, et al. (2006). A Multimodel Ensemble Forecast Framework: Application to spring seasonal flows in the Gunnison River Basin. Water Resources Research 42: Wo9404.

https://doi.org/10.1029/2005WRoo4653

Pardo-Iguzquiza E, Collados-Lara AJ, Pulido-Velazquez D (2017) Estimation of the spatiotemporal dynamics of snow covered area by using cellular automata models. Journal of Hydrology 550: 230-238. https://doi.org/10.1016/j.jhydrol.2017.04.058

Parajka J, Andréassian SA, Archfield, et al. (2013) Prediction of runoff hydrographs in ungauged basins. In: Blöschl et al. (eds.), Runoff Prediction in Ungauged Basins. Cambridge University Press. pp 227-269. https://doi.org/10.1017/CBO9781139235761.013

Parajka J, Blöschl G (2006) Validation of MODIS snow cover images over Austria. Hydrology and Earth System Science 10: 679-689. https://doi.org/10.5194/hess-10-679-2006

Rutter N, Essery R, Pomeroy J, et al. (2009) Evaluation of forest snow processes models (SnowMIP2). Journal of Geophysical Research 114(D6). https://doi.org/10.1029/2008JD011063

Schulz K, Herrnegger M, Wesemann J, et al. (2016) Kalibrierung COSERO - Mur für ProVis, Final report. Institute for Water Management, Hydrology and Hydraulic Engineering. University of Natural Resources and Life Science, Vienna, Austria. (In German)

Stanzel P, Kahl B, Haberl U, et al. (2008) Continuous hydrological modelling in the context of real time flood forecasting in alpine Danube tributary catchments. IOP Conference Series: Earth and Environmental Science 4: 012005. https://doi.org/10.1088/1755-1307/4/1/012005

Stern H, Davidson NE (2015) Trends in the Skill of Weather Prediction at Lead Times of 1-14 Days. Quarterly Journal of the Royal Meteorological Society 141 (692). John Wiley \& Sons, Ltd: 2726-36. https://doi.org/10.1002/qj.2559

Suberu MY, Mustafa MW, Bashir N (2014) Energy storage systems for renewable energy power sector integration and mitigation of intermittency. Renewable and Sustainable Energy Reviews 35: 499-514. https://doi.org/10.1016/j.rser.2014.04.009

Thirel G, Salamon P, Burek P, et al. (2013) Assimilation of MODIS Snow Cover Area Data in a Distributed Hydrological Model Using the Particle Filter. Remote Sensing 5: 58255850. https://doi.org/10339o/rs5115825

Thornthwaite CW, Mather JR (1957) Instructions and Tables for Computing Potential Evapotranpiration and the Water Balance. Publications in Climatology 10: 85-243

Tolson BA, Shoemaker CA (2007) Dynamically dimensioned search algorithm for computationally efficient watershed model calibration. Water Resources Research 43: Wo1413 https://doi.org/10.1029/2005WRo04723

Umweltbundesamt (2017). CORINE Landbedeckung 2012. http://www.umweltbundesamt.at/umweltsituation/umweltin fo/opendata/oed_landbedeckung/ (Accessed on 15 June 2017)

Viviroli D, Dür HH, Messerli B, et al. (2007) Mountains of the world, water towers for humanity : Typology, mapping, and global significance. Water Resources Research 43 Wo7447: 123. https://doi.org/10.1029/2006WRoo5653

Zhao H, Wu Q, Hu S, et al. (2015) Review of energy storage system for wind power integration support. Applied Energy 137: 545-553. https://doi.org/10.1016/j.apenergy.2014.04.103 